Resona Jumal Ilmiah Pengabdian Masyarakat Vol. 2, No. 1 (2018) 47-56

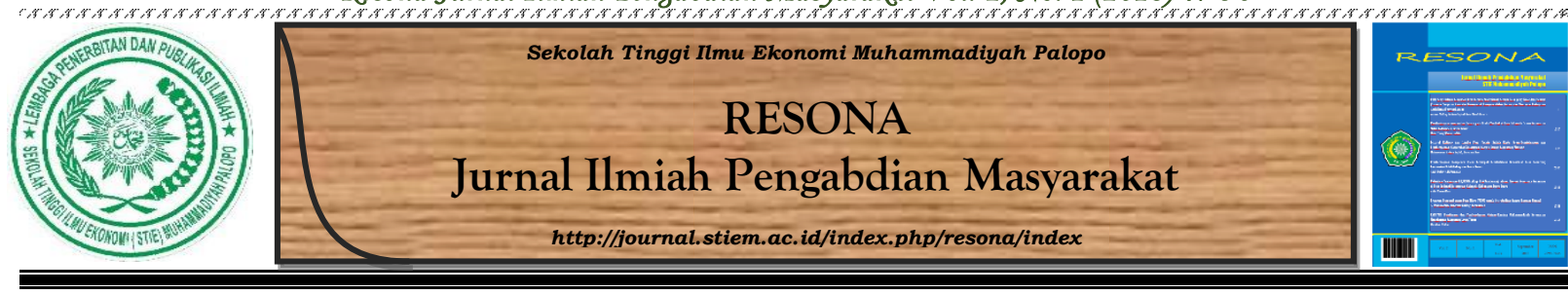

\title{
Program Pengembangan Desa Mitra (PPDM) untuk Mewujudkan Sentra Kentang Unggul
}

\author{
A. Muhibuddin ${ }^{1}$, Jeferson Boling ${ }^{2}$, Fatmawati $^{3}$ \\ ${ }^{123}$ Universitas Bosowa
}

\section{INFO NASKAH \\ Cris Diserahkan \\ 12 Agustus 2018 (Mail) \\ Diterima \\ 13 Agustus 2018 \\ Diterima dan disetujui \\ 03 September 2018}

\section{Kata Kunci:}

Budidaya

Dem area

Kentang

Pembibitan

Pertanian ramah lingkungan

\begin{abstract}
ABSTRAK

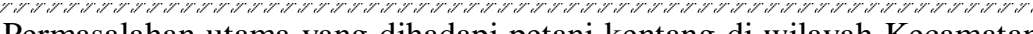
Permasalahan utama yang dihadapi petani kentang di wilayah Kecamatan Ulu Ere, Kabupaten Bantaeng, Provinsi Sulawesi adalah tingginya penggunaan pupuk kimia dan pestisida, produktivitas lahan petani kentang masih sangat rendah serta aspek manajemen yaitu, sistem distribusi benih ke petani yang tidak jelas dan ketersediaan benih yang tidak tepat waktu, baik dari sisi jumlah maupun kualitas. Tujuan program ini dilaksanakan untuk menyelesaikan permasalahan aspek produksi dan manajemen mitra. Metode pelaksanaan kegiatan dari aspek produksi dengan pendekatan: (a) sosialisasi program dan diskusi kelompok; (b) pemberdayaan kelompok tani (teknik pembuatan pupuk organik, teknik pembuatan biopestisida dan teknik pembibitan kentang G3); dan (c) pengembangan (teknik budidaya kentang G4), perbaikan sistem manajemen distribusi benih dan pengembangan usaha industri rumah tangga berbahan kentang. Metode aspek manajemen dilakukan dengan pendekatan: perbaikan pengelolaan produksi benih G3 dan G4. Hasil Program PKM ini adalah: (a) meningkatnya produktivitas lahan petani kentang yang sebelumnya hanya sekitar 9 ton/ha menjadi 16 ton/ha, (b) sistem budidaya kentang yang ramah lingkungan, (c) ketersediaan benih yang tepat, ketepatan waktu distribusi, harga terjangkau dan pelayanan cepat, serta (d) keterampilan pengolahan hasil kentang oleh kelompok tani dan anggota keluarga lainnya menjadi bahan makanan bernilai ekonomi seperti donat kentang, kripik kentang, chip kentang, soup kentang, dan perkedel kentang.
\end{abstract}

\section{Pendahuluan}

Selama ini kebutuhan benih di kecamatan Ulu Ere dan sekitarnya diperoleh dengan harga benih sekitar Rp23.000/kg untuk benih pokok (G3) dan benih G4 (sebar) sekitar Rp20.000/kg. Kebutuhan benih kentang per hektare 1-1,5 ton, sehingga petani harus menyediakan dana antara 23 juta-30 juta rupiah/ha untuk membeli benih (Baharuddin, 2015). Minim dan mahalnya benih yang tersedia menyebabkan petani enggan untuk menggunakan benih bermutu (bersertifikat) untuk dipakai, sehingga produktivitas lahan kentang masih sangat 
rendah (Muhibuddin, et al., 2015; 2016).

Potensi dan peluang agribisnis sesungguhnya kentang sangat menjanjikan keuntungan besar bagi petani jika dikelola secara optimal. Hanya dengan umur tanaman kira-kira 3 bulan, jika tingkat produksi 30 ton/ha dengan harga jual ditingkat petani Rp5000, - maka akan diperoleh 150 juta/musim, menjadikan kentang salah satu komoditas paling menjanjikan untuk meningkatkan kesejahteraan petani. Potensi pasar bibit kentang khususnya di Kecamatan Ulu Ere Kabupaten Bantaeng dan sekitranya masih sangat tinggi (Baharuddin, 2015; Muhibuddin et al., 2017). Luas lahan pertanaman kentang di Kabupaten Bantaeng data tahun 2015 berkisar 2.975 ha dibutuhkan sekitar 4.462,5 ton /musim tanam dengan dua kali penanaman per tahun, dibutuhkan 8.935 ton (BPS, 2016).

Program Pengembangan Desa Mitra (PPDM) bermitra kelompok Tani Passamaturukan memperoleh benih kentang G3 (benih pokok) sebanyak $600 \mathrm{~kg}$ untuk kebutuhan seluas 40 are dan kelompok Tani Mawar akan memperoleh benih kentang G4 (benih sebar) sebanyak 600 kg untuk kebutuhan seluas 1/3 ha. Diharapkan dari benih G3 dan G4 yang akan dihasilkan masing-masing kentang generasi (G4, G5 dan seterusnya), selanjutnya akan disebar/bergulir ke anggota kelompok masing-masing. Selama ini kedua KT/petani tersebut dalam menekuni kegiatan usahanya hanya bermodalkan pengalaman tanpa tersentuh teknologi produksi yang memadai dan hanya mengandalkan penggunaan pupuk buatan/kimia dan penggunaan pestisida yang dijual di pasaran. Bantuan dari pemerintah daerah hanya dalam kegiatan penyuluhan dari Dinas Pertanian Kabupaten, namun secara teknis pengelolaan perbenihan, pembibitan, dan usaha budidaya kentang belum memadai.

\section{Masalah}

Introduksi teknologi produksi pengembangan kentang merupakan hal yang sangat penting dan mendesak karena merupakan permasalahan prioritas sesuai dengan kebutuhan masyarakat di Kecamatan Ulu Ere, Kabupaten Bantaeng untuk menyelesaikan persoalan yang dihadapi selama ini yang diharapkan akan dapat mengakselerasi kualitas dan kuantitas kemajuan Desa Bonto Marannu di bidang tanaman pangan/hortikultura, khusnya komoditi kentang sebagai komoditi unggulan untuk dalam kemandirian dan kesejahteraan masyarakat.

Berdasarkan hasil survei TIM PPDM Universitas Bosowa, secara spesifik permasalahan yang dihadapi Kelompok Tani di wilayah Kecamatan Ulu Ere, terutama pada mitra KT di 
antaranya: (a) tingginya penggunaan pupuk kimia dan pestisida yang berlebihan untuk pertanamannya, (b) produktivitas lahan petani kentang masih sangat rendah, (c) benih sehat dan bermutu mahal, (c) keterampilan dan permodalan petani dalam memproduksi benih masih rendah menyebabkan produktivitas dan mutu yang dicapai juga masih rendah, (d) petani masih menggunakan benih lokal (turun temurun sehingga kualitasnya rendah), dan (e) teknik budidaya yang diterapkan masih konvensional.

Tujuan program PPDM ini adalah untuk membantu mitra dan masyarakat sekitarnya dalam pengembangan pembibitan dan budidaya kentang ramah lingkungan serta manajemen (pengelolaan dan pengolahan hasil) kentang yang diharapkan akan meningkatkan pendapatan mitra dan masyarakat pedesaan..

\section{Metode}

Metode pelaksanaan kegiatan untuk memberi solusi dalam mengatasi permasalahan yang dihadapi mitra dan mendukung Program PKM adalah melalui langkah-langkah dengan tahapan: penyuluhan, peragaan, dan kaji tindak yang terdiri atas:

\section{Aspek Produksi}

Metode pendekatan yang digunakan untuk aspek produksi adalah sebagai berikut:

a. Tahap sosialisasi program dan diskusi kelompok, dengan menghadirkan Kelompok Tani/petani dan tokoh masyarakat. Strategi untuk mencapai sasaran yang diinginkan dengan penilaian participationis. Tahap ini akan dilanjutkan ke tahap pemberdayaan.

b. Tahap pemberdayaan Kelompok Tani/Petani, yang meliputi pembuatan pupuk organik; pembuatan biopestisida; dan pembibitan kentang G3 (benih pokok); dan

c. Tahap pengembangan, meliputi budidaya kentang G4 (benih sebar) dan perbaikan sistem manajemen distribusi benih (khususnya benih G3 dan G4).

\section{Aspek Manajemen Usaha}

Metode pendekatan yang digunakan untuk aspek manajemen usaha adalah sebagai berikut:

a. Pengelolaan produksi benih G3 pada awal kegiatan hanya diberikan pada kelompok tani Gapottang dan benih G4 kepada kelompok tani Mawar yang bertanggung jawab membina masing-masing dua kelompok tani untuk produksi benih dan umbi konsumsi G3 dan G4. Kedua kelompok tani ini masing-masing akan membina dua kelompok tani untuk 
memproduksi benih G3 untuk Kelompok Tani Passamaturukan dan G4 untuk Kelompok Tani Mawar sehingga akan terbentuk 8 (delapan) KT (Kelmpok Tani) binaan. Diharapkan dengan sistem ini akan terbentuk jejaring yang kuat, terkontrol, dan interaktif antar sesama kelompok tani sehingga akan terbentuk kegiatan produksi yang kontinu dan berkesinambungan dalam suatu sistem keterpaduan produk dan pelaku, guna memberikan kepuasan kepada pelanggan.

b. Selain itu, pada pelaksanan program ini, usaha agribisnis yang dapat dilakukn oleh ibu-ibu rumah tangga dan anggota keluarga lainnya secara berkelompok adalah pengolahan hasil kentang misalnya, kripik kentang, donat kentang dan lainnya, sehingga dapat menumbuhkan pastisipasi perempuan dalam usaha perekonomian di desa.

\section{Hasil dan Pembahasan}

Hasil pelaksanaan PPDM Universitas Bosowa yang bermitra dengan sasaran dua Kelompok Tani (KT), yakni: (1) Kelompok Tani (KT) Passamaturukan berlokasi di Desa Marannu yang berdiri tahun 2004 diketuai oleh Jabbar membuat percontohan budidaya kentang Benih Pokok (G3) varietas Granola yang akan menjadi percontohan Kelompok Tani di sekitarnya untuk budidaya kentang dengan penggunaan pupuk Organik; dan (2) Kelompok Tani Mawar berlokasi di Desa Tangnga yang beridir tahun 2002, diketuai oleh Sitti Amar melakukan Demonstrasi Plot (Demplot) kentang Benih Sebar (G4) yang akan menjadi percontohan budidaya kentang di sekitarnya, penggunaan pupuk organik, pestisida nabati, dan fungisida organik. Pelaksanaan Kegiatan yang telah dilakukan adalah sebagai berikut:

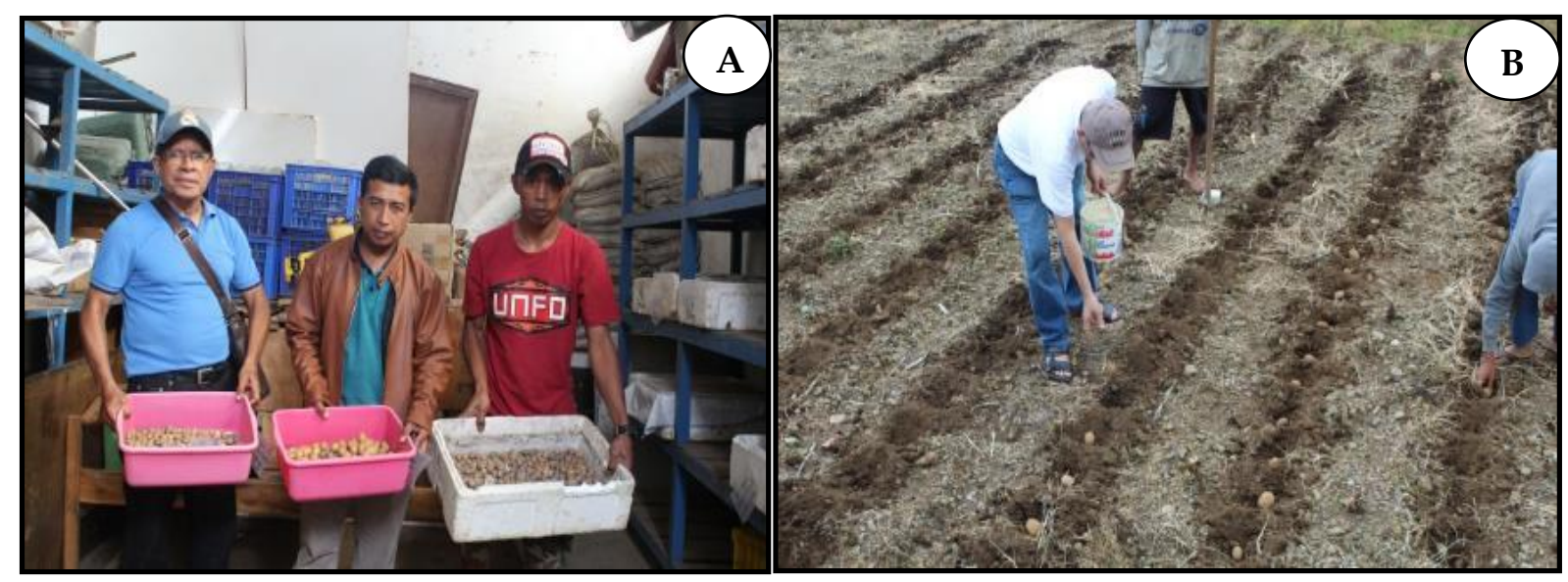




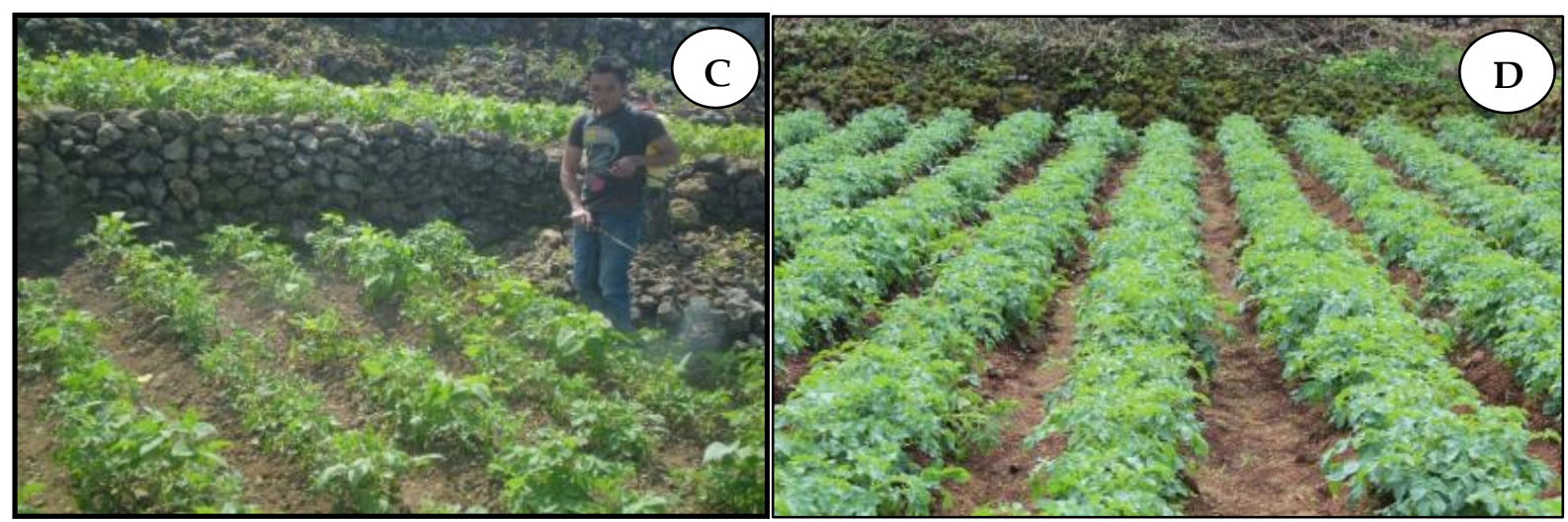

Gambar 1. Teknik Pembibitan Kentang Benih Pokok (G3) Varietas Granola

Pembibitan kentang benih G3 di lahan kelompok tani dengan luas lahan sekitar 1/3 ha dengan jarak tanam (30 x 60) $\mathrm{cm}$ (Gambar 1). Evaluasi pertanaman dan panen didasarkan pada standar prosedur dari Badan Benih Nasional yaitu untuk produksi benih G3 pertanaman harus terbebas dari beberapa penyakit utama, yaitu virus maximal 0,5\%, layu bakteri maksimal 10,0\%, busuk daun maksimal 10,0\%,nematoda sista kuning 0,0\%. Berdasarkan hasil pengamatan Tim PPDM bersama kelompok tani, dan pihak Dinas Pertanian menunjukkan bahwa pada pengamatan kesehatan tanaman (virus, layu bakteri, busuk daun dan nematoda sista kuning masih syarat untuk kelas benih G3, persentase tumbuh di atas $90 \%$ serta pertumbuhan sangat subur (memenuhi syarat Peraturan Menteri Pertanian No.40/ Permentan OT.I/8/2006 tentang Pedoman Perbenihan Kentang).
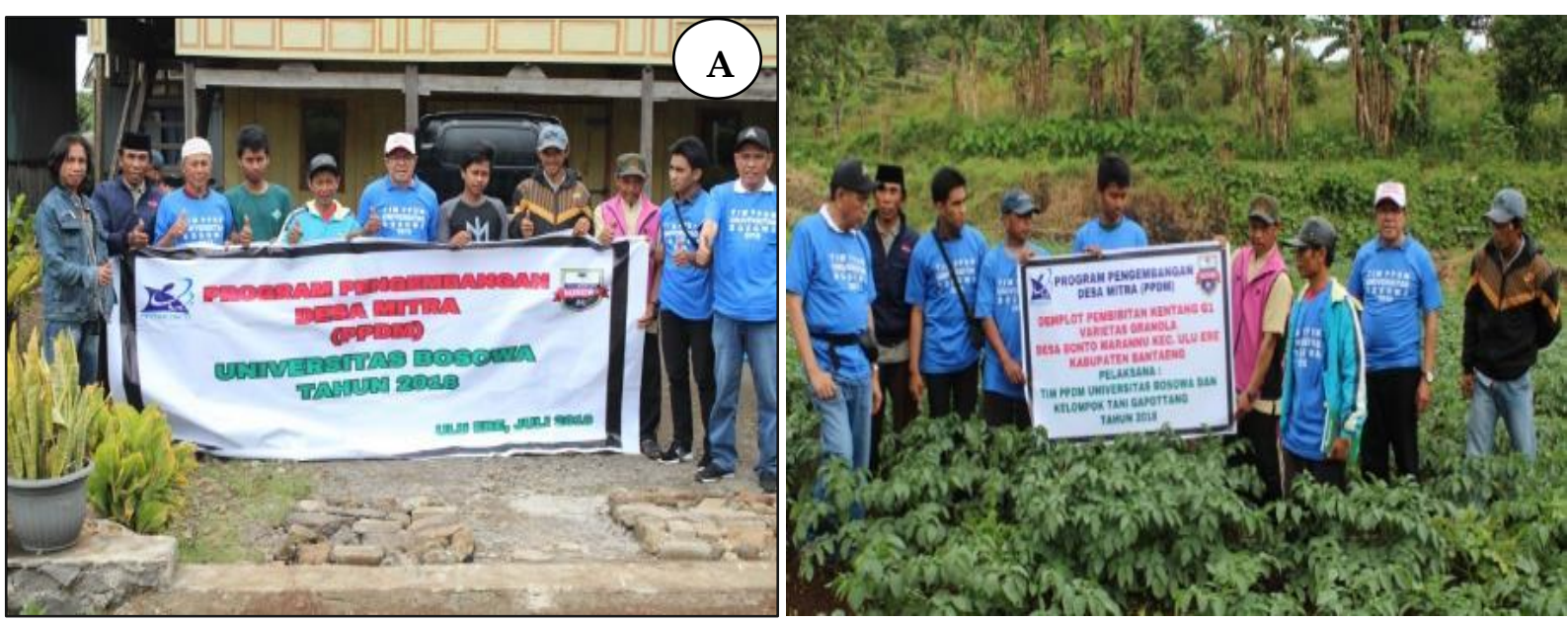


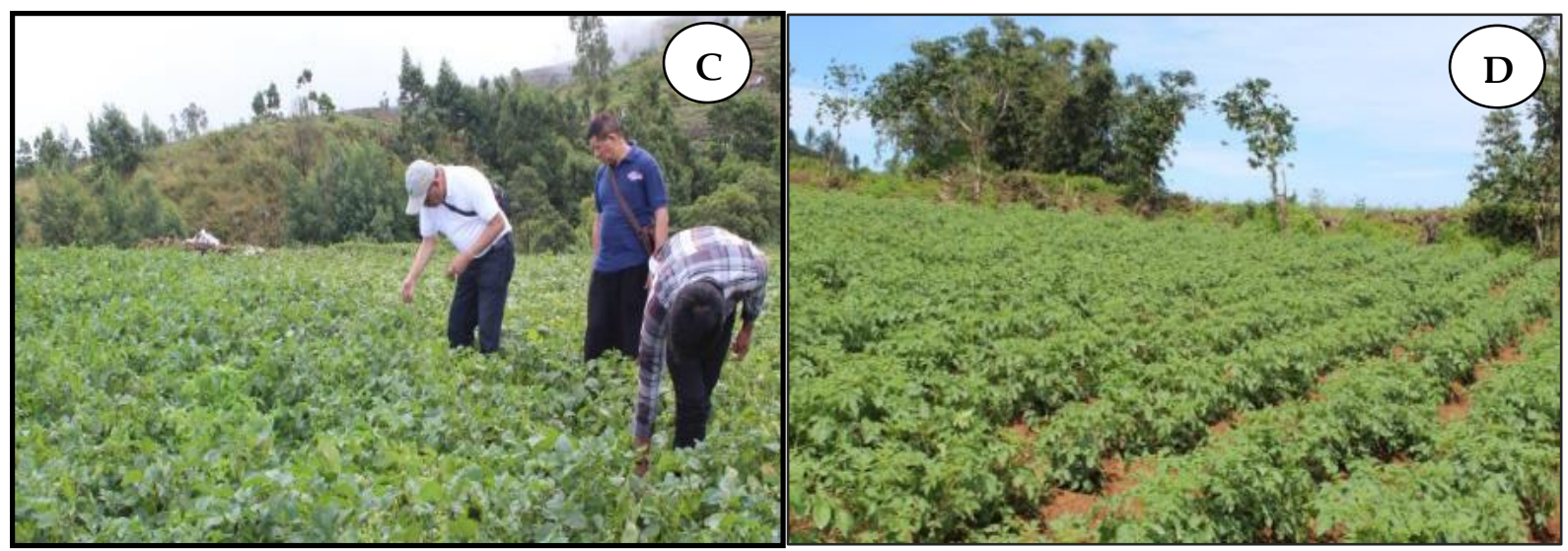

Gambar 2. Percontohan (Dema Area) Budidaya Kentang Benih Sebar (G4)

Dem Area (Demonstrasi Areat) budidaya kentang benih G4 ditanam pada lahan terbuka (Gambar 2), untuk menghasilkan benih G5 (umbi benhi dan konsumsi) oleh Kelompok Tani mitra dengan luas lahan sekitar $1 / 3$ ha dengan jarak tanam (35 x 65) cm. Pengamatan yang dilakukan meliputi: komponen pertumbuhan, komponen produksi dan tingkat serangan OPT. Sebagai bahan evaluasi standar adalah standar pemeriksaan tingkat serangan virus maksimal $0,5 \%$, virus $2,0 \%$, layu bakteri $1,0 \%$, busuk daun $10 \%$, nematoda sista kuning $0,0 \%$. Hasil pengamatan lapangan menunjukkan bahwa pada pengamatan kesehatan tanaman (virus, layu bakteri, busuk daun dan nematoda sista kuning masih memenuhi syarat untuk kelas benih G4, persentase tumbuh di atas $85 \%$ serta pertumbuhan subur (memenuhi syarat Peraturan Menteri Pertanian No.40/Permentan OT.I/8/2006 tentang Pedoman Perbenihan Kentang).
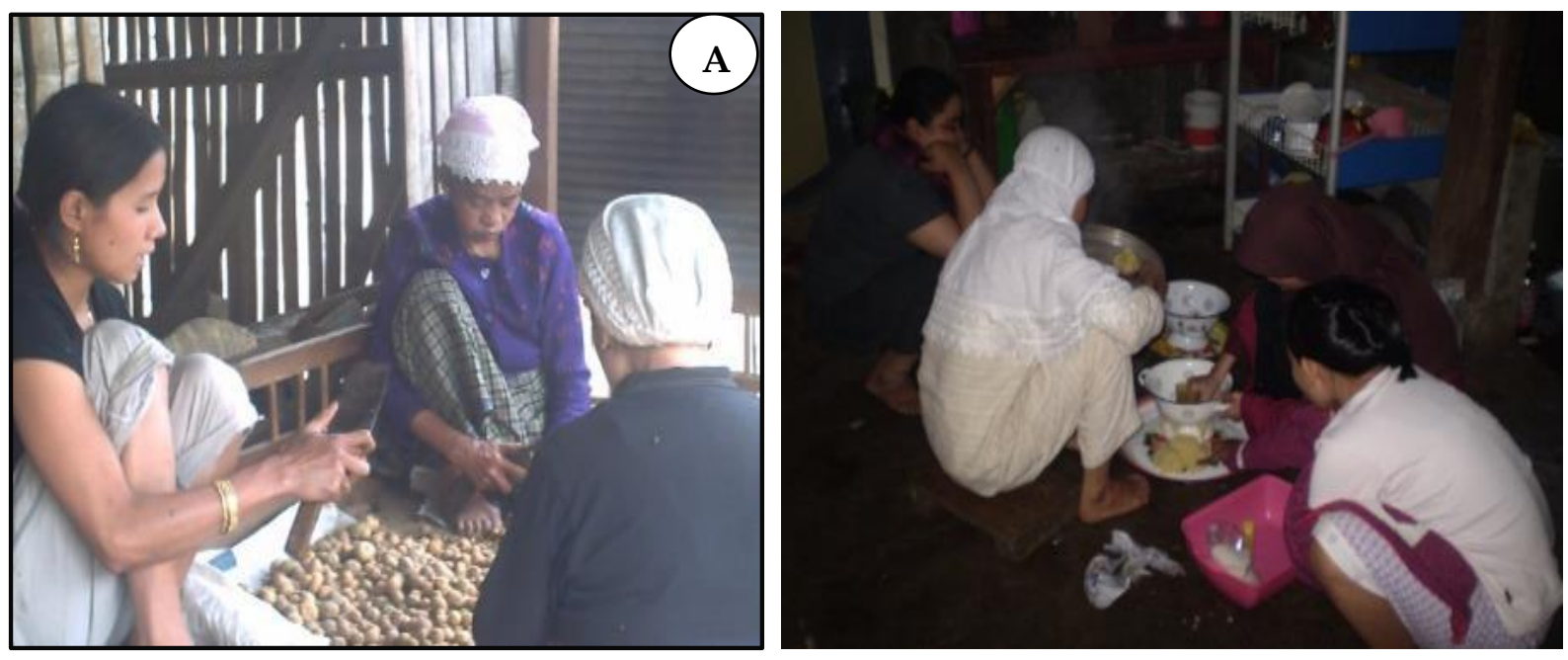

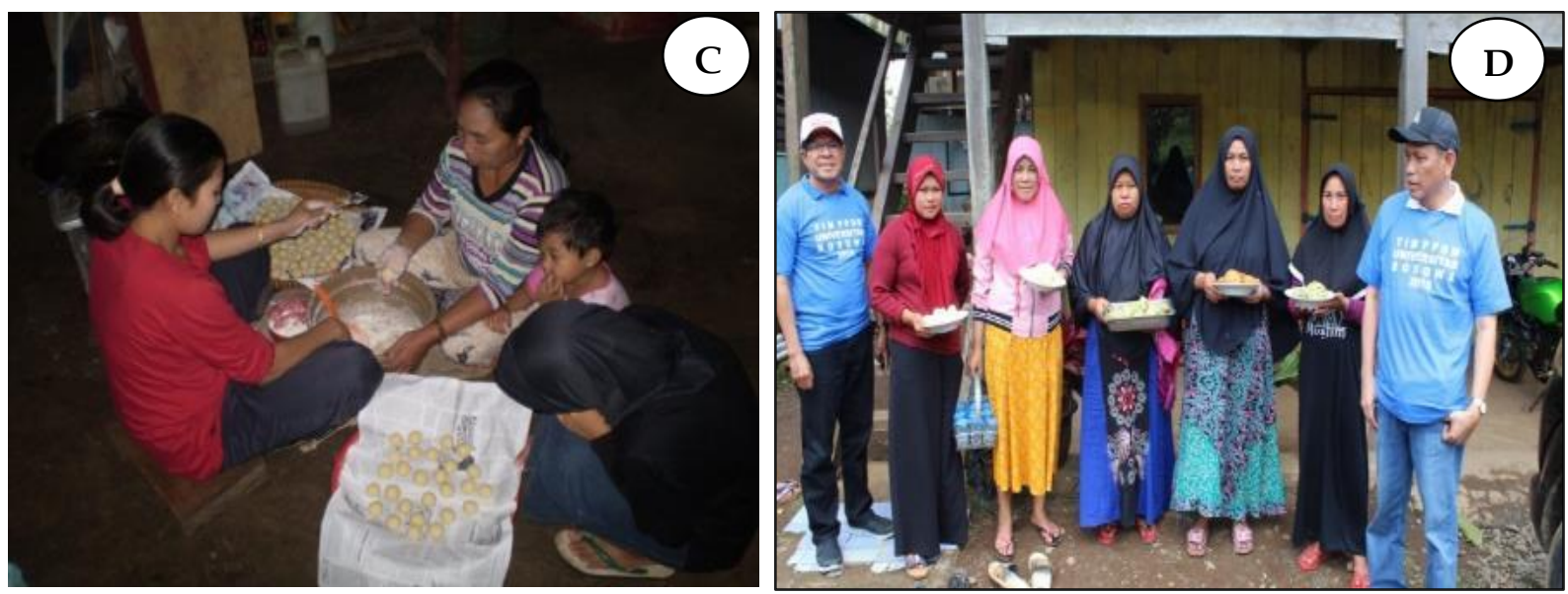

Gambar 3. Pelatihan dan Praktek Pengolahan Pengolahan Makanan

Sosialisasi dan bimbingan pengolahan kentang dilakukan, karena kentang sebagai komoditas sayuran, selain dapat dikonsumsi dalam keadaan segar, juga dapat diolah menjadi berbagai industri makanan rumah tangga. Pemanfaatan kentang yang dilakukan Tim PPDM Universitas Bosowa adalah pelatihan/demonstrasi pembuatan produk makanan berbahan baku kentang yaitu: kentang rebus spesial, perkedel kentang, kripik kentang, dan onde-onde. Pelatihan/demonstrasi pembuatan produk berbahan baku kentang ditunjukkan pada Gambar 3. Berdasarkan hasil sosialisasi dan praktek pengolahan kentang, untuk meningkatkan pendapatan rumah tangga petani menunjukkan bahwa pengetahuan petani dan ibu-ibu rumah tangga di lokasi PPDM meningkat dan partisipasi Ibu-ibu rumah tangga meningkat.

Berdasarkan PPDM yang telah berjalan sekitar enam bulan dilakukan evaluasi secara periodik setiap dua minggu yang melibatkan Tim Dosen Pengusul PPDM, mitra (Kelompok Tani/petani, dan Dinas Pertanian Bantaeng yang telah membantu memonitoring, mengevaluasi, dan mengawasi kesehatan benih dan tanaman di lapangan sebagaimana tercantum pada Tabel 1.

Setelah kegiatan PPDM ini berakhir, semua fasilitas dan material diserahkan kepada kelompok tani pengelola, hasil penjualan benih kentang dan hasil produksi lahan percontohan dijual dan dana investasinya dikeluarkan terlebih dahulu untuk usaha pemeliharaan selanjutnya. Keuntungan yang diperoleh oleh kelompok tani diharapkan sebagian akan digunakan untuk menambah modal usahanya dan menambah perluasan areal penangkaran bibit dan menambah jumlah petani yang terlibat sebagai kelompok tani. Setelah pelaksanaan 
program ini, dalam jangka panjang diharapkan usaha perekonomian yang berbasis pada usaha pembibitan dan budidaya kentang yang ramah lingkungan dapat meningkatkan pendapatan petani.

Pembibitan dan budidaya kentang merupakan salah satu usaha agribisnis yang dapat dilakukan oleh petani sebagai sumber pendapatan baru dan dapat dilakukan oleh ibu-ibu rumah tangga dan anggota keluarga lainnya secara berkelompok sehingga dapat menumbuhkan partisipasi perempuan dalam usaha perekonomian di desa, misalnya terbukanya usaha baru yang bahan baku dari kentang, misalnya kripik kentang, soup kentang, perkedel kentang, kentang rebus dan kentang kukus. Selain itu, diharapkan pelaksanaan selanjutnya dapat berlangsung sistem pertanian yang ramah lingkungan melalui pemanfaatan limbah ternak untuk industri pupuk kandang/organik.

Tabel 1. Hasil Evaluasi Pemeriksaan Lapangan dan Pelatihan Selama Berlangsungnya PPDM

\begin{tabular}{|c|c|c|c|c|c|}
\hline No & Kegiatan & $\begin{array}{l}\text { Waktu } \\
\text { Monitorin/ } \\
\text { evaluasi }\end{array}$ & Indikator & $\begin{array}{l}\text { Tolok Ukur } \\
\text { Yang digunakan }\end{array}$ & $\begin{array}{l}\text { Hasil } \\
\text { Evaluasi }\end{array}$ \\
\hline 1 & $\begin{array}{l}\text { Teknik } \\
\text { Pembibitan } \\
\text { Kentang G3 }\end{array}$ & $\begin{array}{l}45 \text { HST } \\
60 \text { HST } \\
75 \text { HST } \\
90 \text { HST }\end{array}$ & $\begin{array}{l}\text {-Keseragaman } \\
\text {-kesehatan tan }\end{array}$ & $\begin{array}{l}\text { - Isolasi }(10 \mathrm{~m}) \\
\text { - Campuran varietas } \\
\quad(0,1 \%) \\
\text { - Virus }(0,1 \%) \\
\text { - Layu bakteri }(10 \%) \\
\text { - Busuk daun }(10 \%) \\
\text { - Nematoda }(0,0 \%)\end{array}$ & $\begin{array}{l}\text { Memenuhi } \\
\text { Kesehatan tanaman }\end{array}$ \\
\hline 2 & $\begin{array}{l}\text { Dem Area } \\
\text { Kentang G4 } \\
\text { Ramah } \\
\text { Lingkungan }\end{array}$ & $\begin{array}{l}45 \text { HST } \\
60 \mathrm{HST} \\
75 \mathrm{HST} \\
90 \mathrm{HST}\end{array}$ & $\begin{array}{l}\text {-\%tumbuh } \\
\text {-Keseragaman } \\
\text {-kesehatan tan } \\
\text {-Produktivitas }\end{array}$ & $\begin{array}{l}\text { - Isolasi }(10 \mathrm{~m}) \\
\text { - Campuran varietas } \\
(0,5 \%) \\
\text { - Virus }(2 \%) \\
\text { - Layu bakteri }(10 \%) \\
\text { - Busuk daun }(10 \%) \\
\text { - Nematoda }(0,0 \%) \\
\text { - Produktivitas }(>15 \\
\text { ton/ha) }\end{array}$ & $\begin{array}{l}\text { - Memenuhi } \\
\text { Standar } \\
\text { - Produktivitas } \\
18 \text { ton/ha }\end{array}$ \\
\hline 3 & $\begin{array}{l}\text { Pelatihan/Demont } \\
\text { rasi Produk } \\
\text { Makanan } \\
\text { Berbahan Baku } \\
\text { Kentang }\end{array}$ & $\begin{array}{l}60 \mathrm{HSP} \\
90 \mathrm{HST}\end{array}$ & $\begin{array}{l}\text {-Hasil } \\
\text { Pengolahan } \\
\text { kentang }\end{array}$ & $\begin{array}{l}\text { Pengetahuan petani \& } \\
\text { keluarganya } \\
\text { meningkat }\end{array}$ & $\begin{array}{l}\text { - Pengetahuan } \\
\text { petani meningkat } \\
\text { - Partisipasi Ibu- } \\
\text { ibu Rumah } \\
\text { tangga petani } \\
\text { meningkat } \\
\end{array}$ \\
\hline
\end{tabular}

Keterangan : HST = Hari Setelah Tanam, HSP = Hari Setelah Program

Aspek competitivenes produk, pembibitan, dan budidaya kentang hasil kultur jaringan yang dikombinasi dengan penggunaan pupuk organik, diharapkan menjadi produk benih 
unggul, sehingga keuntungan komparatif daerah, harga benih dapat ditekan 50\% dari harga benih dari Jawa. Keunggulan lain bibit G3 dan budidaya kentang G4 hasil kultur jaringan adalah berkurangnya biaya untuk penanggulangan hama dan penyakit, khususnya penyakit yang terbawa oleh umbi.

Benih G3 dan G4 yang dipasarkan oleh petani bisa ditanam petani sampai generasi berikutnya, sehingga selain untuk dikonsumsi sebagian, masih dapat ditanam sebagai benih untuk 2-3 musim tanam (G4 dan G5 ). Produk pertanian dari hasil pertanian organik nilai jualnya lebih tinggi jika dijual di swalayan atau restoran karena konsumen semakin mengerti akan pentingnya mengkonsumsi makanan yang sehat, bebas dari residu pupuk dan pestisida. Jika selama ini produktivitas lahan kentang konsumsi hanya berkisar 8 ton/ha atau dengan nilai 16 juta rupiah, dengan introduksi teknologi perbenihan kentang ramah lingkungan dapat meningkatkan produksi dua kali lipat, yaitu 20-30 ton/ha atau dengan nilai 30-50 juta rupiah/ha. Produktivitas ini telah dicapai pada panen tanaman kentang oleh kelompok tani pengelola.

\section{Simpulan dan Saran}

Hasil yang diperoleh dalam PPDM ini adalah: (a) teknik pembibitan kentang G3 menghasilkan produksi secara signifikan (sebelumnya 8 ton/ha menjadi 14 ton/ha) dan memenuhi standar kesehatan benih (berdasarkan Peraturan Menteri Pertanian No. 40/Permentan/ot/8/2006 tentang Perbenihan Kentang); (b) Dem Area kentang G4, memenuhi syarat kesehatan tanaman, pertumbuhan tanaman dan produksi meningkat secara signifikan (16 ton/ha), dan maupun kualitas umbi serta; (c) Pelatihan/pengolahan produk makanan berbahan baku kentang meningkatkan partisipasi ibu-ibu rumah tangga dan pengetahuan pengolahan makanan berbahan baku kentang. Disarankan agar hasil PPDM ini dapat diadopsi dan dikembangkan oleh kelompok tani di wilayah Kecamatan Ulu Ere, serta PPDM ini dilanjutkan pada tahun-tahun berikutnya dengan membandingkan sumber benih dari perbanyakan konvensional dan perbanyakan secara kultur jaringan.

\section{Ucapan Terima Kasih}

Tim PPDM tahun 2018 Universitas Bosowa menyampaikan terima kasih atas bantuan dana dari DRPM Kemenristek Dikti sehingga program ini dapat berjalan sesuai rencana dan 
ucapan yang sama kami haturkan Kepada Dinas Pertanian Kabupaten Bantaeng, Sulawesi Selatan atas bantuan Sarana dan Prasarana.

\section{Daftar Pustaka}

Baharuddin. 2015. Percepatan dan Peningkatan Penyediaan Benih Kentang Unggulan di Koridor Sulawesi melalui Pemanfaatan Paket Inovasi Teknologi untuk Mendukung Swasembada Benih Nasional. Laporan Akhir Penelitian Unggulan Strategis Nasional. Universitas Hasanuddin.

BPS. 2016. Bantaeng dalam Angka. Badan Pusat Statistik. Kabupaten Bantaeng.

Muhibuddin, A., Z. Razak, A. Halik, dan J. Boling. 2015. Growth and Production of Two Varieties of Potatoes in Plains Medium with Methanol Supplements. International journal of current research and academic review 3 (5): 330-340.

Muhibuddin, A., Z. Razak, S. Salam, dan J. Boling, 2016. Development of Potato Plants as the Results of Aeroponic Technology by Treating of Methanol in Plain Medium at Ulu Ere Sub District, Bantaeng Regency, South Sulawesi, Indonesia. International Journal of Current Research and Academic Review 4 (9): 140-348.

Muhibuddin, A., S. Salam, Z. Razak, dan J. Boling, 2017. The yield response and Quality of Potato as Aeroponics Technology Results Towards Methanol and Gliricidia sepium Leaf Extract in Medium Plain. J. Advances in Environmental Biology 11 (1): 1-9. 